\title{
Diet and Lifestyle in the First Villages of the Middle Preceramic: Insights from Stable Isotope and Osteological Analyses of Human Remains from Paloma, Chilca I, La Yerba III, and Morro I
}

\author{
David G. Beresford-Jones (1D, Emma Pomeroy, Camila Alday, Robert Benfer, Jeffrey Quilter, \\ Tamsin C. O'Connell, and Emma Lightfoot
}

\begin{abstract}
We present stable isotope and osteological data from human remains at Paloma, Chilca I, La Yerba III, and Morro I that offer new evidence for diet, lifestyle, and habitual mobility in the first villages that proliferated along the arid Pacific coast of South America (ca. $6000 \mathrm{cal} \mathrm{BP}$ ). The data not only reaffirm the dietary primacy of marine protein for this period but also show evidence at Paloma of direct access interactions between the coast and highlands, as well as habitual mobility in some parts of society. By locating themselves at the confluence of diverse coastal and terrestrial habitats, the inhabitants of these early villages were able to broaden their use of resources through rounds of seasonal mobility, while simultaneously increasing residential sedentism. Yet they paid little substantial health penalty for their settled lifestyles, as reflected in their osteological markers of stature and stress, compared with their agriculturalist successors even up to five millennia later. Contrasting data for the north coast of Chile indicate locally contingent differences. Considering these data in a wider chronological context contributes to understanding how increasing sedentism and population density laid the foundations here for the emergence of Late Preceramic social complexity.
\end{abstract}

Keywords: stable isotope analysis, human osteology, Middle Preceramic, Middle Archaic, marine resources, mobility, Pacific coast, South America

En el siguiente articulo presentamos datos osteológicos e isótopicos provenientes de restos humanos de los sitios la Paloma, Chilca I, La Yerba III y Morro I. Estas investigaciones ofrecen nueva evidencia sobre la dieta, el estilo de vida y la movilidad habitual entre los primeros pueblos que proliferaron a lo largo de la árida costa del Pacífico de Sudamérica (ca. 6000 cal BP). Los datos reafirman la primacía dietética de proteínas marinas para este período, pero también muestran en la Paloma evidencia de interacciones de acceso directo entre la costa y la sierra, y de movilidad habitual de algunos sectores de la sociedad. Al ubicarse en la confluencia de diversos hábitats costeros y terrestres, los habitantes de estas primeras aldeas pudieron ampliar el uso de los recursos a través de rondas de movilidad estacionales, al mismo tiempo que aumentaron su sedentarismo residencial. Sin embargo, pagaron baja penalización de salud por sus estilos de vida sedentarios, reflejados en sus marcadores osteológicos de estatura y estrés en comparación con la de sus sucesores agrícolas, incluso hasta cinco milenios después. Los datos contrastantes de la costa norte de Chile indican diferencias contingentes a nivel local. Considerando estos datos en un contexto cronológico más amplio este análisis contribuye a comprender cómo el aumento del sedentarismo y la población sentó las bases para el surgimiento de la complejidad social del Precerámico Tardío.

David G. Beresford-Jones - Heinz Heinen Centre for Advanced Study, University of Bonn Heussallee 18-24, D-53113 Bonn, Germany (david.beresfordjones@gmail.com, corresponding author)

Emma Pomeroy, Camila Alday, and Tamsin C. O'Connell a Department of Archaeology, University of Cambridge, Downing St., Cambridge CB2 3DZ, UK (eep23@cam.ac.uk; cca28@cam.ac.uk; tco21@cam.ac.uk)

Robert Benfer - Department of Anthropology, University of Missouri, 112 Swallow Hall, Columbia, MO 65211, USA (BenferR@missouri.edu)

Jeffrey Quilter Peabody Museum of Archaeology and Ethnology, Harvard University, 11 Divinity Avenue, Cambridge, MA 02138, USA (quilter@fas.harvard.edu)

Emma Lightfoot $\square$ McDonald Institute for Archaeological Research, University of Cambridge, Downing St., Cambridge CB2 3ER, UK (elfl2@cam.ac.uk)

Latin American Antiquity 32(4), 2021, pp. 741-759

Copyright (C) The Author(s), 2021. Published by Cambridge University Press on behalf of the Society for American Archaeology. This is an Open Access article, distributed under the terms of the Creative Commons Attribution licence (http://creativecommons.org/licenses/by/4.0/), which permits unrestricted re-use, distribution, and reproduction in any medium, provided the original work is properly cited.

doi:10.1017/laq.2021.24 
Palabras clave: análisis de isótopos estables, osteología humana, Precerámico Medio, Arcaico Medio, recursos marinos, movilidad, costa del Pacífico, América del Sur

$\mathrm{A}$ long the Pacific west coast of South America, a long Middle Preceramic period $^{1}$ (ca. 7000-5000 BP) bears many Mesolithic-like hallmarks, including a broadening resource base and increasing sedentism, population density, and social complexity. Here, as elsewhere, logistically organized, complex hunter-gatherers reduced their mobility by locating themselves in so-called ecotonally diverse settings: places where different habitats conjoined, offering access to diverse resources according to seasonal rounds (Beresford-Jones et al. 2015; Standen et al. 2017).

Coasts and estuaries are quintessential ecotonally diverse environments, providing rich, sustainable, and easily seen and harvested resources. In many places worldwide, Mesolithic broad-spectrum economies seem to have relied on the systematic exploitation of marine resources (Stiner 2001). Nowhere, however, is the connection between the development of sedentism and coastal productivity more relevant than the Pacific coast of South America. Although the littoral itself is arid desert, it is traversed by numerous riverine oases along the watercourses that rise in its Andean hinterlands, and its offshore marine resources are prodigious, sustained by nutrients in cold upwellings that today make the seas off the coast of Peru the world's richest fishery (FAO 2014).

Moseley's (1975) Maritime Foundations of Andean Civilization (MFAC) hypothesis suggested that Late Preceramic civilization first arose along this coast based on the exploitation of marine resources, challenging the axiom that agriculture is necessary for the rise of complex societies. However, terrestrial resourcesincluding gathered and, increasingly, cultivated plant foods - are also evident in the Preceramic archaeological record, so that precisely how subsistence patterns unfolded here as agriculture emerged continues to be debated (Prieto and Sandweiss 2020). Although many sites are reported dating to the end of the Middle Preceramic when settled villages first started to coalesce along this Pacific coast, the "type-site" for this period has long been Paloma on the south-central coast of Peru (Figure 1).

In this article we present a refined chronological context for three of the first villages on the Peruvian coast-Paloma, Chilca I, and La Yerba III-by calibration and Bayesian modeling of their radiocarbon dates. We then present the results of stable isotope analyses of 33 individuals - 29 interred at Paloma, 1 from Chilca I, and 3 from La Yerba III-alongside osteological analyses of 62 individuals interred at Paloma and 28 at Morro I on the north coast of Chile. Together these data offer direct evidence of diet and lifestyle for the critical period foreshadowing the emergence of Late Preceramic civilization on this Pacific coast.

\section{The Archaeological Context: The First Villages of the Middle Preceramic}

The early village sites of Paloma and Chilca I both lie in the Chilca Valley on the central coast of Peru, 3.5 and $4.5 \mathrm{~km}$ from the Pacific Ocean, respectively, whereas La Yerba III is on the Río Ica on the south coast of Peru, $2.5 \mathrm{~km}$ from the sea (Figure 1). Morro 1, meanwhile, is not a habitation site but a cemetery at Arica on the north coast of Chile that contains multiple "Chinchorro" inhumations over many millennia, although habitation sites in its vicinity provide further insight into lifestyles persisting over that time. All these sites enjoy remarkable preservation conditions in an arid climate.

Although the archaeological records of Paloma, Chilca I, La Yerba III, and Morro I therefore entail some differences, not least in their respective time depths, they each have contemporaneous components dating to around 6000 cal BP, as shown in Figure 2, with broadly comparable material cultures and human ecologies.

\section{Permanent Settlement, Increasing Population, and Intensifying Networks}

The archaeological assemblages at Paloma, Chilca I, La Yerba III, and Morro I reflect a prolongation of marine hunting and gathering 


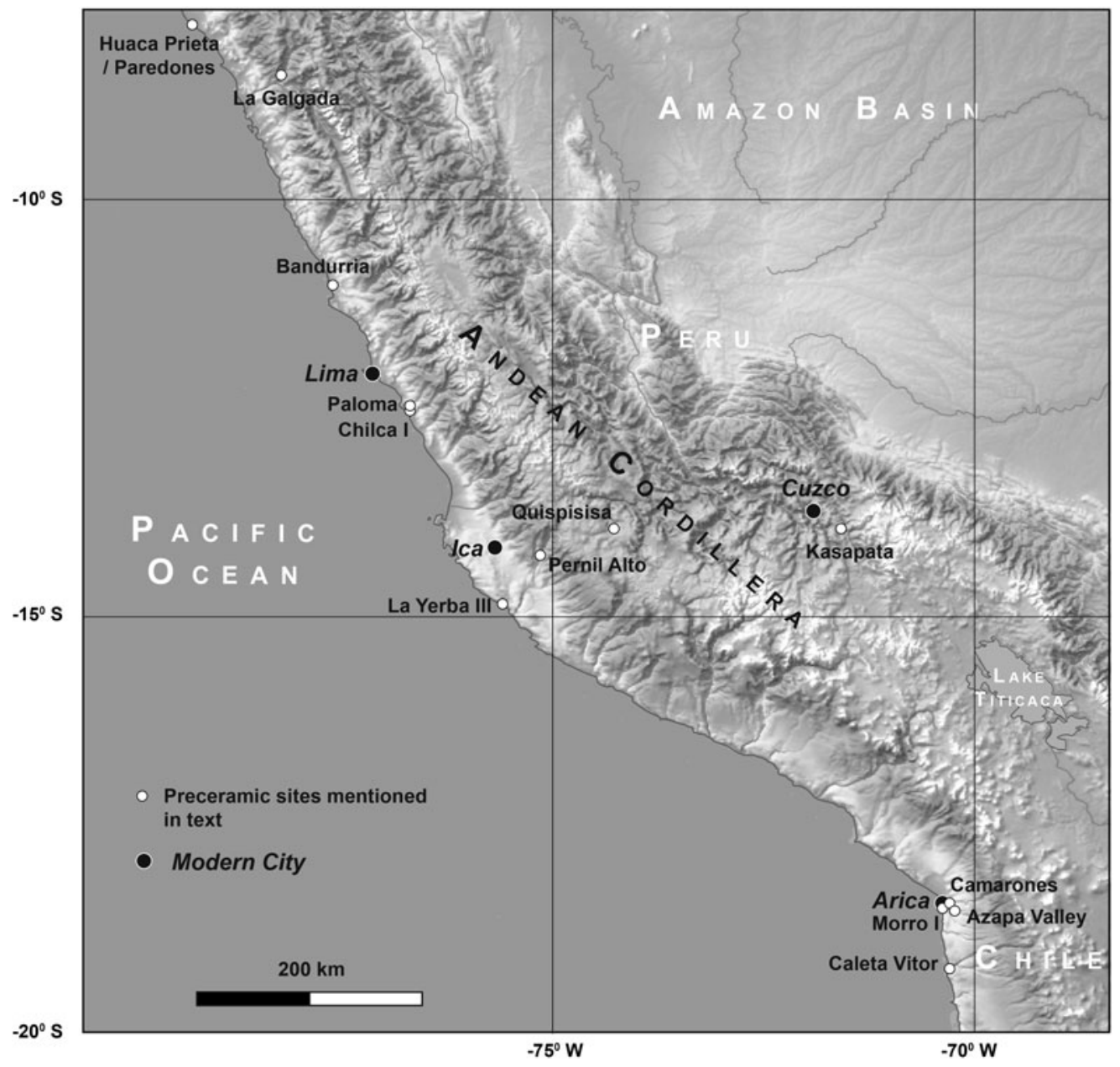

Figure 1. The Pacific coast of South America showing the Preceramic sites discussed in the text.

lifestyles that had endured along this littoral since its first occupation, although the distribution and availability for human harvesting of marine resources changed over time, with variations both in the El Niño Southern Oscillation (ENSO; Sandweiss et al. 2020) and in coastal morphology, itself subject to changing eustatic sea levels until around $6000 \mathrm{BP}$.

Paloma, Chilca I, and La Yerba III show some of the earliest evidence for permanent, sedentary occupation in the Peruvian archaeological record. Their locations were determined, first, by proximity to permanent sources of freshwater. Coastal rivers here have highly seasonal surface flow, but especially in their lower reaches, groundwater supplies are easily accessible year-round (Engel
1991:58). Each of these villages comprises sequences of circular or ovoid semi-subterranean houses excavated into middens of previous occupations. The houses were constructed of frames of willow posts and sedge canes covered with finely woven mats of fibrous sedges or cattails; there was a small central hearth, and often they were separate patio areas with other hearths. Interiors were kept clean, with multilayered floor deposits showing continued occupation though time and containing heavy grinding stones (batanes), anvils, other furniture of whalebone, and multiple storage pits. The dead were interred with care and ritual, as individuals or sometimes in groups, in structured pit burials within the houses after their abandonment (Benfer 2008; Beresford- 
OxCal v4 3.2 Bronk Ramsey (2017); r:5 SHCal13 atmospheric curve (Hogg et al 2013)

\section{PaLoma}

UGa 4121, Layer 300 (Benfer 1984: 552)

UGa 4119, Layer 300 (Benfer 1984: 552)

D-AMS 033015, Layer 300

UGa 4208, Layer 400 (Benfer 1984: 552)

UGa 4117, Layer 400 (Benfer 1984: 552)

\section{ChILCA I}

1-835, Layer 900 (Engel 1988: 14)

I-892, House XIII (Kaplan \& Lynch 1999: 266)

I-892, Layer 800 (Engel 1988: 14)

\section{La Yerba III}

OxA-31362, Cateo 1, SU 7007 (Beresford-Jones et al. 2018: 401)

OxA-32290, Trench 3, SU 9020 (Beresford-Jones et al. 2018: 401)

OxA-32291, Trench 3, SU 9009 (Beresford-Jones et al. 2018: 401)

OxA-35803, Trench 1, SU 9511 (Beresford-Jones et al. 2018: 401)

\section{MORRo I}

I-13651, T28C9 (Standen 1997)

T23C5 (Standen 1997)

I-13543, T23C7 (Standen 1997)

I-13650 T19C1 (Allison et al. 1984)

T23C12 (Standen 1997)

DRI-3450, 10b (Standen 1997)

DRI-3449, 10b (Standen 1997)

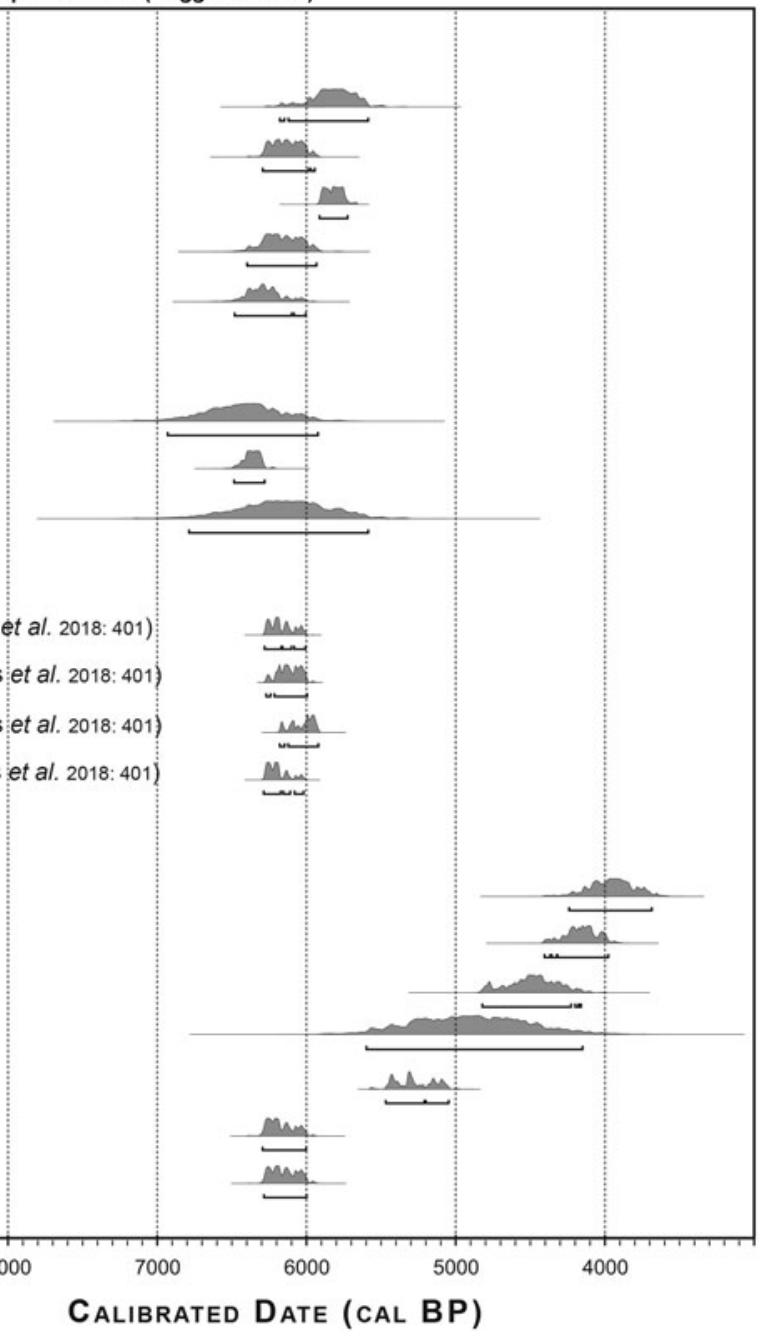

Figure 2. Radiocarbon dates for Paloma, Chilca I, La Yerba III, and Morro I, all calibrated using ShCal13 (Hogg et al. 2013).

Jones et al. 2018; Engel 1980, 1988; Gorbahn 2020; Quilter 1989; Supplemental Figure 1).

Along with these various traits of sedentism, including early hints of agriculture to be discussed shortly, came significant demographic change and increasing social complexity. Investigations at Paloma and La Yerba suggest population increases of around an order of magnitude through the millennium to $6000 \mathrm{cal} \mathrm{BP}$ (Benfer 2008:372; Beresford-Jones et al. 2018; Reitz 2003).

Obsidian lithics at Paloma (Benfer 2008) and La Yerba III (Chauca et al. 2019) derive from the Jichja Parco quarry at Quispisisa at $4,100 \mathrm{~m}$ asl in the Ayacucho highlands, which is $170 \mathrm{~km}$ and $310 \mathrm{~km}$ distant, respectively, from those sites. They are evidence for wide spheres of interaction, although how these materials arrived at the coast remain unknown.

\section{Previous Dietary Evidence}

Well-preserved archaeological assemblages offer copious, albeit indirect, evidence of ancient diet in these early villages. Middens at Paloma (Reitz 2003) and La Yerba III (Beresford-Jones et al. 2015, 2018) are manifestly dominated by a wide spectrum of hunted and gathered marine 
resources. These include pelagic fish such as sea bass (Cilus gilberti) and smaller net-caught fish such as anchovy (Ergraulis ringens) and sardines (Sardinops sagax). Marine mammals, particularly sea lions (Otaria flavescens); edible kelps (Macrocystis spp.); and shellfish, such as various mussels (Mytilidae) and large Concholepas gastropods, were hunted and gathered from rocky littorals. Resources gathered from sandy beaches include crustaceans such as the mole crab (Emerita analoga) and surf clams (Mesodesma donacium). Proliferating in dense beds in shallow waters along sandy beaches and resilient to overexploitation, the latter offered the perfect protein resource for marine hunter-gatherers: they were easily collected without significant risk by all members of society and easily opened in quantities over small fires. Estuarine resources include summer-spawning mullet (Mugil cephalus), crayfish (Cryphiops caementarius), and diverse aquatic birds and eggs (Benfer 2008; Beresford-Jones et al. 2015, 2018; Reitz 2003; Weir and Derring 1986).

Habitation sites on the north coast of Chile, broadly contemporaneous with the burials at Morro I, are also dominated by marine resources, including mollusks, crustaceans, fish, birds, and marine mammals (Bearez et al. 2016; Salazar et al. 2018; Santoro et al. 2017; Standen et al. 2017). Middens at sites such as Caleta Vitor suggest a long-term reliance on relatively few species of easily seen and collected mollusks and echinoderms, including urchins (Loxechinus sp.), chitons (Acanthopleura echinata), limpets (Fissurella sp.), abalones (Concholepas sp.), and mussels (Santoro et al. 2017).

Yet, even though marine resource exploitation is certainly highly visible in the Middle Preceramic middens along this Pacific coast, most, if not all, of these middens also include significant evidence of terrestrial resources, hunted and gathered according to seasonal rounds from adjacent riparian and lomas fog oasis habitats. These resources include guanaco (Lama guanicoe) and deer (Odocoileus virginianus) at Paloma (Reitz 2003:78) and La Yerba III (Beresford-Jones et al. 2015) and vizcachas (Lagidium viscacia), guinea pigs (Cavia porcellus), and dogs (Canis familiaris) at La Yerba. Land snails (Bostryx sp.) proliferate in winter lomas and comprise $14 \%$ of the total mollusk assemblage at La Yerba III (Beresford-Jones et al. 2015) and are found in smaller proportions at Paloma (Reitz 2003).

Gathered and, increasingly, cultivated plant foods are also evident. Wild roots and tubers such as the rhizomes of Cyperaceae esculentus provided sources of starch at Paloma (Benfer 2008; Weir and Derring 1986), La Yerba III (Beresford-Jones et al. 2015), Huaca Prieta (Bonavia et al. 2017), and sites on the north coast of Chile (Ugalde et al. 2021). Cultivated food plants at Paloma, Chilca I, and La Yerba III include the earliest directly dated lima beans (Phaseolus lunatus) at Chilca I (6485-6280 cal BP), La Yerba III (6270-5996 cal BP), and Paloma; jack beans (Canavalia ensiformis) at Chilca I and La Yerba III; and guava (Psidium guajava) at Paloma and La Yerba III (BeresfordJones et al. 2018; Kaplan and Lynch 1999; Weir and Derring 1986). At Huaca Prieta's Phase 3, corresponding to this period (Bonavia et al. 2017:368; Grobman et al. 2012), and at Paredones, these and other food crops are reported, including avocado (Persea americana), chili peppers (Capsicum spp.), and maize (Zea mays). At sites along the north coast of Chile, achira (Canna sp.), sweet potato (Ipomoea batatas), manioc (Manihot esculenta), and perhaps maize are reported (Ugalde et al. 2021). By the end of the Middle Preceramic after 5300 cal BP, subsistence at Pernil Alto, located some $50 \mathrm{~km}$ inland from La Yerba, was predominantly based on food crops (Gorbahn 2020), including beans (Phaseolus and Canavalia spp.), sweet potato, achira, and pumpkin (Cucurbita sp.), supplemented by gathered Prosopis pods and hunting. By the Late Preceramic, food cultivars proliferate at many sites along the coast of Peru (Pearsall 2008).

Yet for all the richness of these data, quantified comparisons of the relative significance of these foodstuffs to the ancient diet are compromised by differential taphonomy, sampling, and analyses. Tiny schooling fish such as anchovy are underrepresented in most practical recovery methods, whereas durable shellfish remains may well be overrepresented. Plant foods are typically inconspicuous for various taphonomic reasons (Reinhard et al. 2011; 
Weir and Derring 1986). So, whereas faunal remains suggest that fish dominated Paloman diets (Reitz 2003:71), coprolite analyses suggest that they were instead composed largely of shellfish, with significant plant components (Weir and Derring 1986:39). Coprolite analyses of burials at Morro I (Reinhard et al. 2011:Table 5) and quantified archaeobotanical analyses of many sites along the north coast of Chile (Ugalde et al. 2021: Figure 3) also suggest more significant plant components to diets than hitherto widely recognized. Indeed, pace Moseley's (1975) MFAC hypothesis, archaeological orthodoxy now ascribes earlier and greater significance to cultivated food plants in coastal Preceramic diets (Prieto and Sandweiss 2020), albeit often underpinned by microfossil data with their own limitations of context and dating (Mercader et al. 2018). For all these reasons then, questions remain about the trajectory of subsistence change that underpinned the increases in population foreshadowing the emergence of Late Preceramic social complexity in the wider Andean region. Here we contribute some direct evidence of diet and lifestyle from the first sedentary villages of the Middle Preceramic, epitomized by Paloma.

\section{Scientific Background}

\section{Stable Isotope Analysis}

Stable isotope analysis of human remains provides individual, semi-quantitative evidence for past diets because chemical differences in those diets are transmitted through the food chain and recorded in body tissues. Isotopic signatures record general consumption so that at least $20 \%$ of protein must derive from a particular isotopically distinct source for it to be detectable (Hedges 2003).

Stable carbon isotope ratios $\left(\delta^{13} \mathrm{C}\right)$ can distinguish between marine and terrestrial food chains because each have carbon sources with different isotope values (Lee-Thorp 2008). $\delta^{13} \mathrm{C}$ values can also distinguish between diets based on plants following different $\mathrm{C}_{3}$ and $\mathrm{C}_{4}$ photosynthetic pathways (O'Leary 1988). Although most economically important plants are of the $\mathrm{C}_{3}$ type, some such as maize use the $\mathrm{C}_{4}$ photosynthetic pathway. Moreover, around one-third of wild edible plants on the south coast of Peru are $\mathrm{C}_{4}$, and these plants may also enter the human food chain after being consumed by animals that in turn are eaten by people (Cadwallader et al. 2012).

Stable nitrogen isotope ratios $\left(\delta^{15} \mathrm{~N}\right)$ provide an indication of the amount of animal protein in diets, because $\delta^{15} \mathrm{~N}$ values increase by $3 \%-5 \%$ with each step in a trophic chain (Bocherens and Drucker 2003; O'Connell et al. 2012). Food chains in aquatic ecosystems tend to be longer than in terrestrial ecosystems, leading to relatively elevated $\delta^{15} \mathrm{~N}$ values in the former (Lee-Thorp 2008). People consuming diets high in marine foods are therefore characterized by having both high $\delta^{13} \mathrm{C}$ and high $\delta^{15} \mathrm{~N}$ values.

In this study, we analyzed bone and dentine collagen (protein). Bone collagen reflects diet over the majority of adult life so that small dietary inputs or changes in diet may not be detectable (Hedges et al. 2007). Dentine collagen, meanwhile, reflects the diet over the time of tooth formation during childhood (Gage et al. 1989). $\delta^{15} \mathrm{~N}$ values reflect only the protein component of the diet, whereas carbon in bone collagen predominantly reflects dietary protein combined with carbon from other dietary fractions (Ambrose and Norr 1993; Tieszen and Fagre 1993).

\section{Human Osteology}

Adult stature is frequently used as a cumulative marker of health and nutrition during growth in studies of health and standards of living in both ancient and modern populations (Bogin and Keep 1999; Steckel 2009; Tanner 1987). Osteological analyses suggest that in many parts of the world (Cohen and Armelagos 1984; Mummert et al. 2011), including the Peruvian central coast (Pechenkina et al. 2007), the initial transition to agriculture caused stature and health to decline, attributed in part to an increased disease burden caused by concomitant sedentism (Cohen and Armelagos 1984; Larsen 2006). Data from the north coast of Chile suggest relatively short stature and fairly poor health among the Chinchorro buried at Morro I and other cemeteries (Arriaza and Standen 2006, 2008; Pomeroy 2012) attributed to sedentism facilitated by rich marine resources rather than by agriculture, and therefore persisting after the adoption of agriculture. Previous studies on the Peruvian and Chilean Pacific coasts have, 


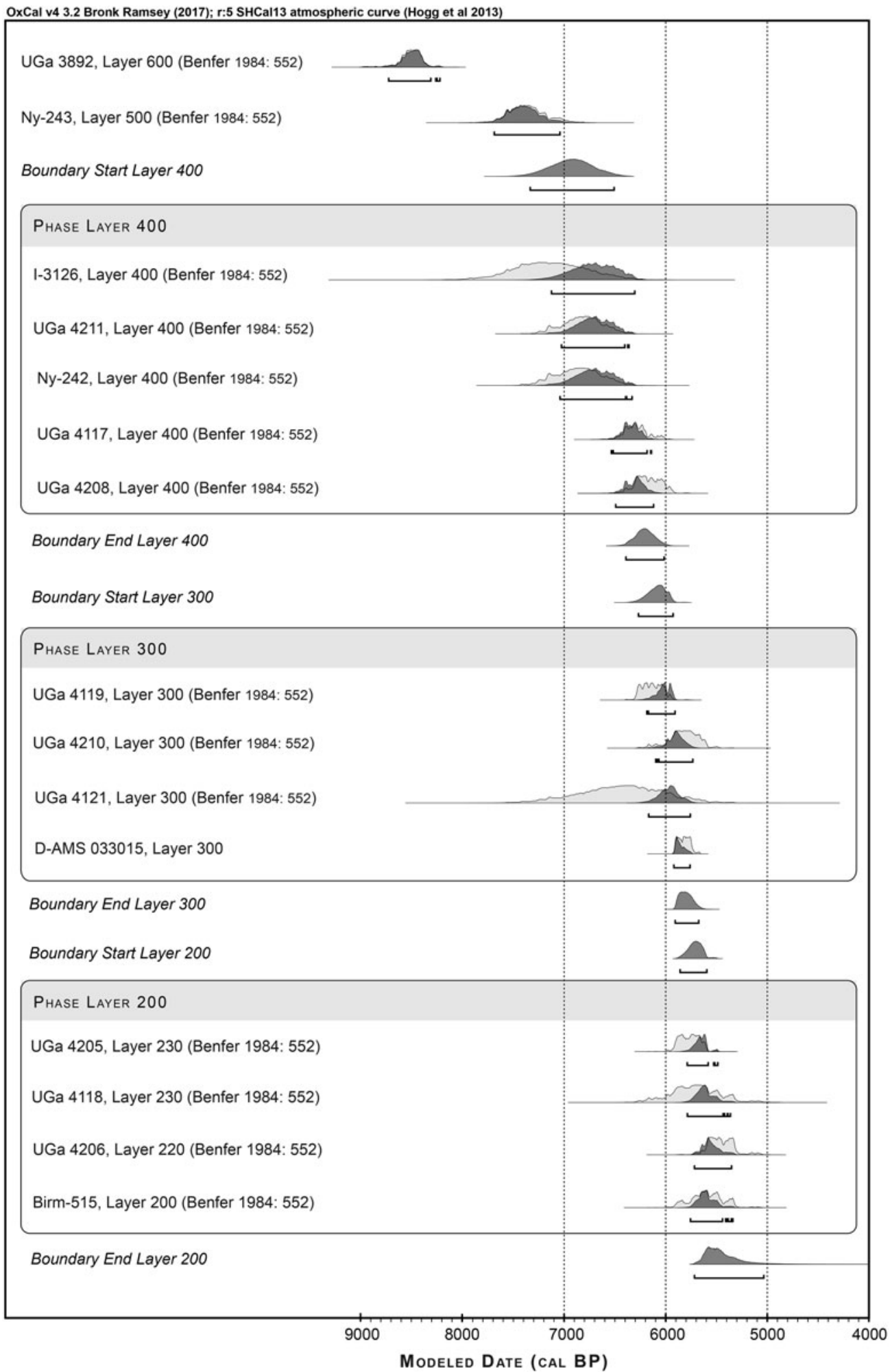

Figure 3. New and published radiocarbon dates for Paloma calibrated using ShCal13 (Hogg et al. 2013) and then modeled using OxCal's Bayesian analysis following Bronk Ramsey (2009), in a sequence of phases, according to their reported stratigraphic sequence. 
however, varied in their methods used to estimate stature, limiting the comparability of data between sites and regions. Here we estimate stature using a consistent methodology and apply equations specifically derived for South American Andean populations (Pomeroy and Stock 2012) to long bone lengths of adults from Paloma and Morro I.

Another common observation in osteological analyses of human remains is that the transition to agriculture in many parts of the world is accompanied by decreased levels of habitual mobility - presumably due to the much greater sedentism that accompanies agricultural lifestyles as compared with that of hunter-gatherers (Mummert et al. 2011; Ruff et al. 1984). Cross-sectional geometry of the femoral and tibial midshafts provides direct skeletal evidence for habitual mobility levels because the amount and distribution of bone in the cross-section of shafts are influenced by loading patterns. Higher ratios of maximum to minimum bending rigidity $\left(I_{\max } / I_{\min }\right)$ of the femur reflect higher habitual mobility levels (Ruff 2008). In this study, we also examined cross-sectional geometric properties of the femoral midshaft to explore potential links between diet, mobility, and stature in skeletal samples from Paloma and Morro I. Examining patterns of habitual mobility may help elucidate whether differences between two main study regions in stature and temporal trends in height may relate to any contrasts in behavior, diet, or both.

\section{Materials and Methods}

We calibrated previously published (Benfer 1984; Beresford-Jones et al. 2018; Engel 1988; Kaplan and Lynch 1999; Standen 1997, 2003) and new (see Supplemental Table 1) radiocarbon dates for Paloma, Chilca I, La Yerba III, and Morro I using ShCal13 (Hogg et al. 2013). Twenty-one radiocarbon dates for Paloma were modeled using OxCal v4.3's Bayesian analysis (following Bronk Ramsey 2009) as a sequence of phases to define boundary limits for the site's published stratigraphy (Supplemental Table 2). Twenty-five radiocarbon dates for Paloma's Layers 300 and 400, Chilca I, La Yerba III, and the earliest tomb contexts at Morro I were then modeled using
OxCal as a single, contiguous phase to test the hypothesis that components of these sites were contemporaneous (Supplemental Table 3).

Collagen was extracted (following Privat et al. 2002) from human bone samples from 29 Palomans, three bone and two dentine samples from three individuals from La Yerba III, and one bone sample from Chilca I. Reliable yields for stable isotopic data were obtained from eight of those from Paloma, two of those from La Yerba III, and the individual from Chilca I (Table 1; Supplemental Text 1).

Osteological analyses of stature (following Pomeroy and Stock 2012) and femoral midshaft biomechanics $\left(I_{\max } / I_{\min }\right)$ were carried out on human bone samples from 62 individuals from Paloma and 28 from Morro I (Table 2; Supplemental Table 4; see Supplemental Text 1 for full details of all methods, laboratory procedures, and statistical analyses).

\section{Results}

\section{Chronology}

Reliable collagen extractions from Palomans all derive from Layer 300, with the exceptions of one individual from Layer 400 (Burial 84, PAL 10) and one from Layer 100 surface contexts (Burial 2, PAL 01), directly dated to 1182-981 cal BP and therefore not considered further here (Supplemental Tables 1 and 2). OxCal Bayesian modeling of Paloma's radiocarbon dates as a sequence of phases gives median boundary limits of between 6077 and 5802 cal BP for Layer 300 and between 6914 and 6204 cal BP for Layer 400 (Figure 3; Supplemental Table 2). Because of her unusual data and interment, which are discussed later, Burial 110 (PAL 13) was dated directly (D-AMS 033015; Supplemental Tables 1 and 3) to 5913-5725 cal BP and thereby confirmed to be contemporaneous with Layer 300.

Of the 28 Morro I burials analyzed osteologically here, five were directly dated (Figure 2), whereas others can be dated by association with varying degrees of precision (Supplemental Table 5). Seven likely date to Phase 1, 6252$5690 \mathrm{cal} \mathrm{BP}$, which is approximately contemporary with the Middle Preceramic Peruvian villages (Standen 2003). Nineteen date to Phases 2 and 3 and postdate the Peruvian villages by one to two 
Table 1. Results of Stable Isotope Analyses of Individuals from Paloma, Chilca I, and La Yerba III.

\begin{tabular}{|c|c|c|c|c|c|c|c|c|c|c|c|c|}
\hline Site & Sample Code & Burial No. & Context & Sex* & Age at Death* & Element & $\%$ Yield & $\% \mathrm{C}$ & $\% \mathrm{~N}$ & $\mathrm{C}: \mathrm{N}$ & $\delta^{13} \mathrm{C}(\%)$ & $\delta^{15} \mathrm{~N}(\%)$ \\
\hline \multirow{2}{*}{ La Yerba III } & LY1 & 1 & SU 7006, Cateo 1 & & & Molar & 8.4 & 34.7 & 13.1 & 3.1 & -15.1 & 15.3 \\
\hline & LY2 & 2 & SU 7006, Cateo 1 & & & Premolar & 3.6 & 25.1 & 9.3 & 3.2 & -14.1 & 16.8 \\
\hline \multirow[t]{29}{*}{ Paloma } & PAL01 & 2 & 100 & M & Adult & Rib & 16.7 & 44.0 & 15.9 & 3.2 & -11.9 & 14.9 \\
\hline & PAL02 & 11 & 500 & $\mathrm{~F}$ & Adult & Rib & 1.7 & Fail & & & & \\
\hline & PAL03 & 13 & 300 & M & Adult & $\mathrm{Rib}$ & 2.0 & Fail & & & & \\
\hline & PAL04 & 27 & 500 & $?$ & Fetus? (27A) & Femur & 0.0 & Fail & & & & \\
\hline & PAL05 & 35 & $300 ?$ & $?$ & Non-adult (approx. 7 years) & Femur & 1.8 & Fail & & & & \\
\hline & PAL06 & 39 & 300 & $\mathrm{~F}$ & Adult & Rib & 2.6 & 24.2 & 8.4 & 3.4 & -15.2 & 15.2 \\
\hline & PAL07 & 47 & 500 & M & Adult & Rib & 1.7 & Fail & & & & \\
\hline & PAL08 & 75 & 300 & $\mathrm{~F}$ & Adult & Rib & 2.9 & 3.6 & 0.6 & 7.1 & Fail & \\
\hline & PAL09 & 83 & 300 & M & Adult & Rib & 0.0 & Fail & & & & \\
\hline & PAL10 & 84 & 400 & $\mathrm{~F}$ & Adult & Rib & 1.6 & 44.0 & 15.3 & 3.4 & -13.0 & 17.5 \\
\hline & PAL11 & 85 & 300 & $\mathrm{~F}$ & Adult & Femur & 3.9 & Fail & & & & \\
\hline & PAL12 & 101 & 200 & M & Adult & Rib & 0.0 & Fail & & & & \\
\hline & PAL13 & 110 & $? 300$ & $\mathrm{~F}$ & Adult & Rib & 15.0 & 46.5 & 17.2 & 3.2 & -17.6 & 9.9 \\
\hline & PAL14 & 117 & 300 & $\mathrm{M}$ & Adult & $\mathrm{Rib}$ & 3.4 & 42.7 & 15.4 & 3.2 & -12.6 & 17.7 \\
\hline & PAL15 & 119 & 200 & $\mathrm{~F}$ & Adult & Rib & 0.0 & Fail & & & & \\
\hline & PAL16 & 141 & 400 & $\mathrm{~F}$ & Adult & $\mathrm{Rib}$ & 0.0 & Fail & & & & \\
\hline & PAL17 & 143 & 300 & M & Adult & Rib & 4.2 & Fail & & & & \\
\hline & PAL18 & 159 & 300 & M & Adult & Rib & 0.0 & 13.7 & 3.2 & 5.0 & Fail & \\
\hline & PAL20 & 210 & 200 & $\mathrm{M}$ & Adult & Rib & 0.0 & Fail & & & & \\
\hline & PAL21 & 212 & 300 & $\mathrm{~F}$ & Adult & Rib & 1.3 & 29.9 & 10.1 & 3.5 & -14.5 & 16.6 \\
\hline & PAL22 & 215 & 220 & $\mathrm{~F}$ & Adult & Rib & 0.0 & Fail & & & & \\
\hline & PAL23 & 218 & 230 & $\mathrm{~F}$ & Adult & Rib & 0.0 & 8.5 & 2.6 & 3.8 & Fail & \\
\hline & PAL24 & 220 & 400 & M & Adult & Femur & 0.0 & Fail & & & & \\
\hline & PAL25 & 222 & 220 & $\mathrm{~F}$ & Adult & Rib & 0.0 & Fail & & & & \\
\hline & PAL26 & 228 & 230 & M & Adult & Rib & 0.0 & Fail & & & & \\
\hline & PAL27 & 229 & 300 & $\mathrm{~F}$ & Adult & Rib & 2.0 & 31.0 & 11.1 & 3.3 & -13.0 & 16.4 \\
\hline & PAL28 & 238 & 300 & $\mathrm{M}$ & Adult & Rib & 5.3 & 39.5 & 13.9 & 3.3 & -13.0 & 17.9 \\
\hline & PAL29 & 246 & 300 & M & Adult & Rib & 1.6 & Fail & & & & \\
\hline & PAL30 & $142 \mathrm{~B}$ & 300 & M & Adult & $\mathrm{Rib}$ & 1.3 & Fail & & & & \\
\hline Chilca I & PAL19 & 200 & & & & Femur & 11.3 & 43.3 & 15.5 & 3.3 & 13.3 & 16.8 \\
\hline
\end{tabular}

*Sex and age at death data from Quilter (1989). 
Table 2. Comparison of Mean Estimated Adult Statures and Osteological Indicators of Habitual Mobility for Individuals from Paloma and Morro 1.

\begin{tabular}{|c|c|c|c|c|c|c|c|c|}
\hline \multirow[b]{2}{*}{ Variable } & \multirow[b]{2}{*}{ Sex } & \multirow[b]{2}{*}{ Site } & \multirow[b]{2}{*}{$N$} & \multirow[b]{2}{*}{ Mean } & \multirow[b]{2}{*}{$\begin{array}{c}\text { Standard } \\
\text { Deviation }\end{array}$} & \multicolumn{3}{|c|}{ Two-Way ANOVA $p$ Value* } \\
\hline & & & & & & Sex & Site & $\begin{array}{l}\text { Sex } \times \text { Site } \\
\text { Interaction }\end{array}$ \\
\hline \multirow{4}{*}{ Stature $(\mathrm{cm})$} & Male & Paloma & 21 & 163 & 5.70 & \multirow{4}{*}{$<0.001$} & \multirow{4}{*}{$<0.001$} & \multirow{4}{*}{0.06} \\
\hline & & Morro 1 & 15 & 156 & 4.70 & & & \\
\hline & E & Paloma & 23 & 150 & 4.60 & & & \\
\hline & Female & Morro 1 & 12 & 148 & 4.10 & & & \\
\hline \multirow{4}{*}{$\begin{array}{l}\text { Femoral midshaft } \\
\quad \text { biomechanics }\left(I_{\max } / I_{\min }\right)\end{array}$} & $M$ & Paloma & 23 & 1.42 & 0.22 & \multirow{4}{*}{0.002} & \multirow{4}{*}{0.005} & \multirow{4}{*}{0.30} \\
\hline & Mrale & Morro 1 & 13 & 1.26 & 0.15 & & & \\
\hline & \multirow{2}{*}{ Female } & Paloma & 25 & 1.25 & 0.10 & & & \\
\hline & & Morro 1 & 11 & 1.18 & 0.11 & & & \\
\hline
\end{tabular}

* Statistically significant values $(p<0.05)$ are shown in bold.

millennia. Two remaining can only be broadly assigned to the Preceramic. Four Morro I burials previously analyzed for stable isotope ratios (King et al. 2018) likely date to Phase 1, contemporary with the Peruvian villages, whereas a fifth is likely dated to Phase 2, 5185-4415 cal BP (see Supplemental Text 1 for further discussion).

OxCal Bayesian modeling of 25 radiocarbon dates for Paloma's Layers 300 and 400, Chilca I, La Yerba III, and Morro I's T10b tomb context as a single, contiguous phase tests the hypothesis that these specific contexts of these sites were contemporaneous (Supplemental Table 3). Unsurprisingly, a date from Chilca I's surface Layer 600 and four dates from Paloma's Layer 400 , each with previously identified contextual uncertainties or very large standard errors (Benfer 1984:552), show poor agreement indices $(<60)$ with such a model. Setting these as outliers, however, produces an overall agreement index of 97, supporting the hypothesis that components of these four sites are contemporaneous between 6372 and 5848 cal BP (single-phase boundary median start and end dates, respectively, at $95.4 \%$ confidence limit; Figure 4).

\section{Stable Isotope Analyses}

Stable isotope results are shown in Table 1 and Figure 5. Bone collagen data from Palomans have a mean $\delta^{13} \mathrm{C}$ value of $-13.9 \%$ o $( \pm 1.9 \%$, range -17.6 to $-11.9 \%, n=8)$ and a mean $\delta^{15} \mathrm{~N}$ value of $15.8 \%$ o $( \pm 2.6 \%$, 9.9 to $17.9 \%, n=8)$. One outlier is identified: Burial 110 (PAL13, female) has a $\delta^{15} \mathrm{~N}$ value of $9.9 \%$ o (lying more than 1.5 times the interquartile range below quartile 1). This individual also has the lowest $\delta^{13} \mathrm{C}$ value $(-17.6 \%)$, although this is not identified as a statistical outlier. All reliable collagen extractions from Paloma came from Layer 300, with the exception of one from Layer 400 (Burial 84, PAL10), whose isotopic values are similar to other Palomans.

Bone collagen from the single individual from Chilca I (PAL19) has a $\delta^{13} \mathrm{C}$ value of $-13.3 \%$ and a $\delta^{15} \mathrm{~N}$ value of $16.8 \%$, whereas the two dentine collagen results from La Yerba III have $\delta^{13} \mathrm{C}$ values of $-15.1 \%$ and $-14.1 \%$, and $\delta^{15} \mathrm{~N}$ values of 15.3 and $16.8 \%$. Although these sample sizes are too small for statistical comparison, they clearly fall within the range of typical isotopic variation in Layer 300 of Paloma.

\section{Human Osteology}

Osteological results are shown in Table 2 and Supplemental Figure 2. No significant differences in stature or $I_{\max } / I_{\min }$ were found between layers 200, 300, and 400 for either sex at Paloma using two-way ANOVA (see Supplemental Text 1 for further discussion; Supplemental Figure 2). Measurements of Palomans from all layers are therefore combined in comparisons with those at Morro I (see Supplemental Text 1 for further details). For both stature and femoral midshaft $I_{\text {max }} / I_{\text {min }}$, the two-way ANOVA indicated significant differences between sexes and sites $(p<$ $0.05)$, although the interaction effect was not significant $(p<0.05$; Table 2$)$. These results show that males were significantly taller than females 


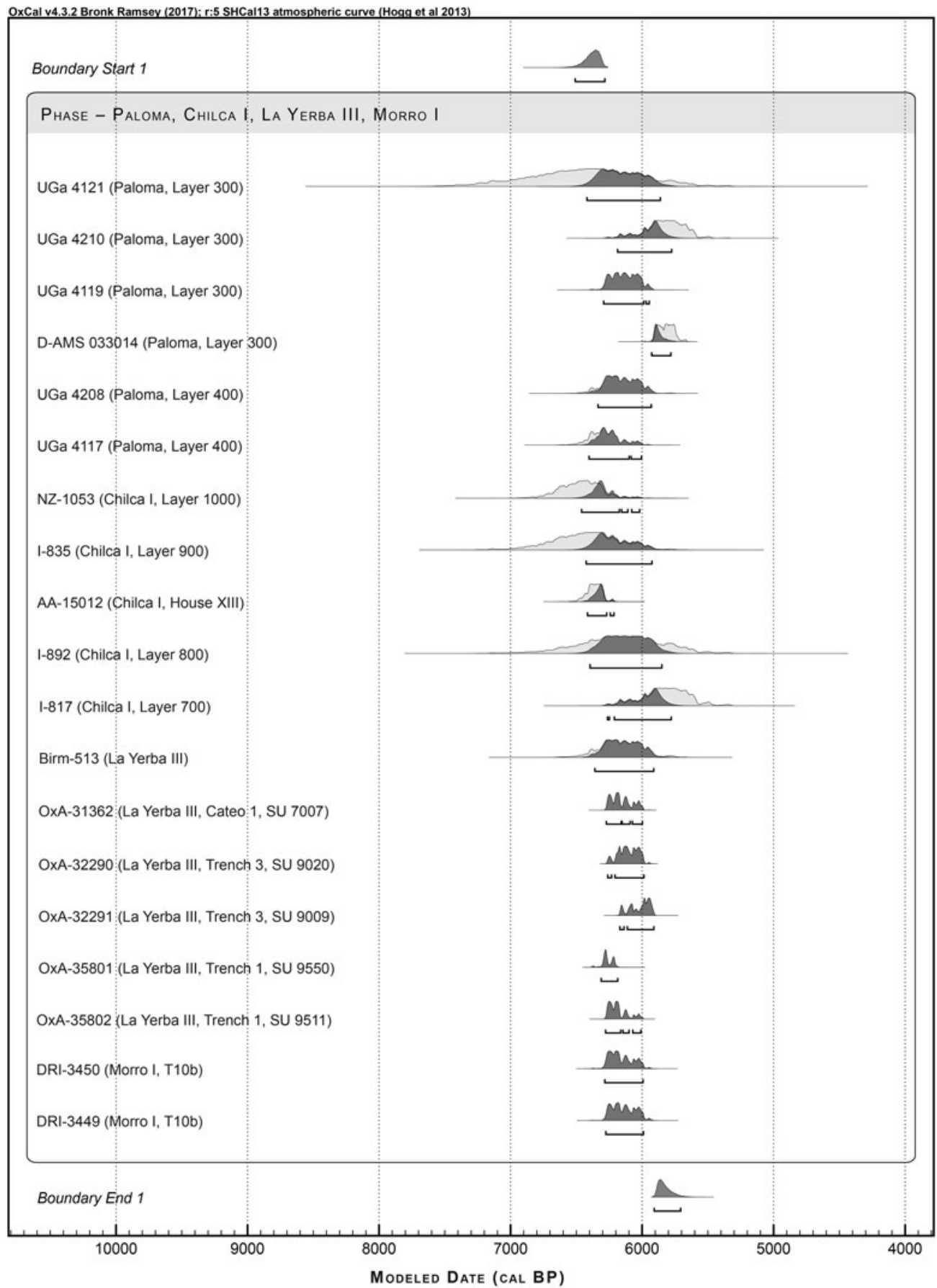

Figure 4. Paloma, Chilca I, La Yerba III, and Morro I radiocarbon dates calibrated using ShCal13 (Hogg et al. 2013 ) and then modeled as a single phase using OxCal's Bayesian analysis following Bronk Ramsey (2009).

in both samples and that Palomans were significantly taller than those from Morro I. Paloman adults show significantly higher femoral midshaft $I_{\max } / I_{\min }$ ratios and, therefore, significantly higher levels of habitual mobility than those from Morro 1 (Table 2). 


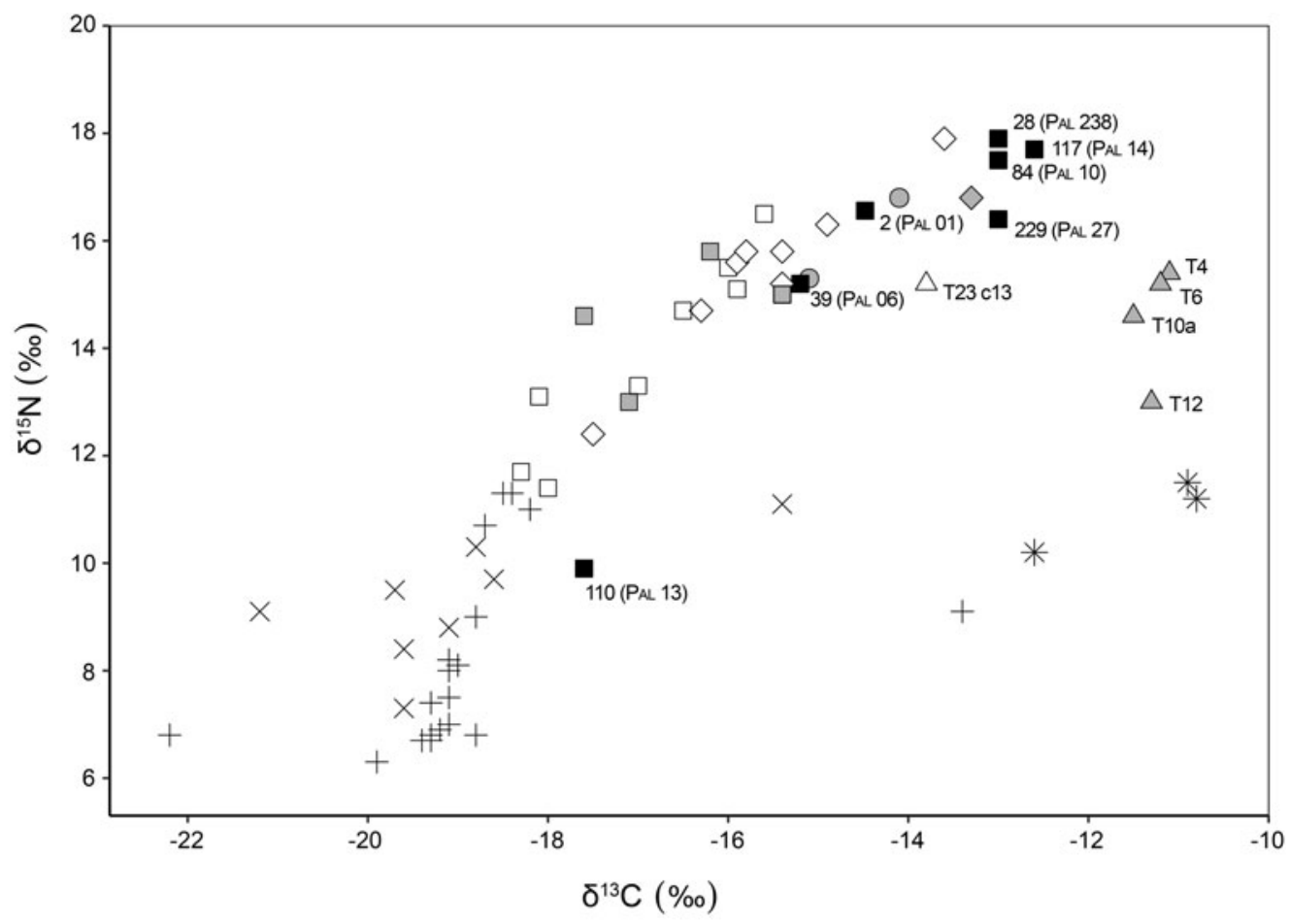

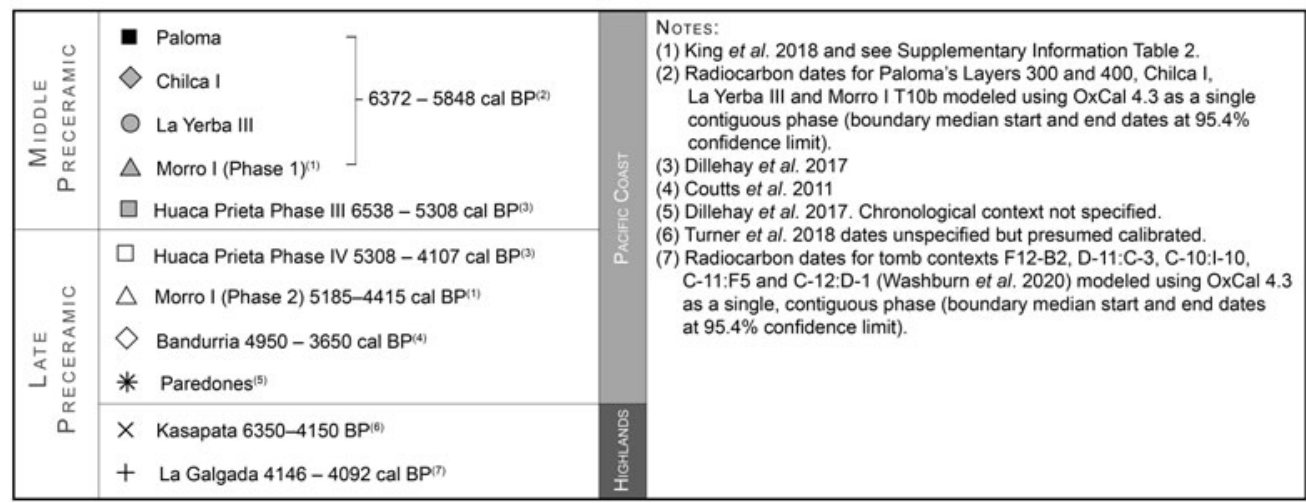

Figure 5. Stable isotope $\delta^{13} \mathrm{C}$ and $\delta^{15} \mathrm{~N}$ values for individuals from Paloma, Chilca I, and La Yerba III (see Table 1) compared with other published stable isotope values from the Preceramic period.

\section{Discussion}

The isotopic and osteological data presented here for Paloma, Chilca I, La Yerba III, and Morro I come from a limited number of individuals but contribute to a larger body of gradually emerging direct evidence for diet and lifestyle in the first villages that proliferated along this Pacific coast around $6000 \mathrm{cal} \mathrm{BP}$ toward the end of the Middle Preceramic period: changes that foreshadowed the emergence of sedentary complex society in the wider Andean region. Calibration and Bayesian modeling of their new and existing radiocarbon dates support the hypothesis that components of these sites were contemporaneous between 6372 and 5848 cal BP (Figure 4; Supplemental Table 3), providing a refined chronological context for the data presented.

No faunal samples were available to evaluate background environmental isotopic variations, but it is nonetheless evident from the stable isotope data that almost all the individuals analyzed 
from Paloma, La Yerba III, Chilca I, and Morro I consumed diets high in marine protein. This evidence corroborates the long-standing presumption, based on multiple lines of archaeological data (Beresford-Jones et al. 2018; Moseley 1975; Prieto and Sandweiss 2020; Quilter 1991), of the critical role of rich marine resources in promoting sedentism and increasing population and social complexity during the Middle Preceramic along this Pacific coast. As discussed, however, quantifying those other lines of indirect data against one another to determine their relative significance to human diet is complicated by uncertainties of taphonomy and sampling: plant foods, in particular, are likely underrepresented for a variety of taphonomic reasons. It is therefore notable that the direct evidence provided by the isotopic values of the inhabitants of these villages continues to assert the generalized primacy of marine protein sources; this is despite the considerable evidence at these sites for hunted and gathered terrestrial foods and, indeed, for incipient agriculture of, for instance, fully domesticated, high-protein beans and, at $\mathrm{La}$ Yerba III, possibly domesticated guinea pigs (Beresford-Jones et al. 2015, 2018; Engel 1991; Kaplan and Lynch 1999; Weir and Derring 1986).

Burial 110 (PAL13), an adult female around 20 years old at death, stands as an exception to this general pattern of significant marine protein consumption at Paloma. Although directly dated as contemporary with other Layer 300 interments, Burial 110's isotopic data suggest a diet comprising little, if any, marine protein (Table 1; Figure 5). She is exceptional too in her unusual interment. Whereas most people at Paloma (and indeed also at Chilca I and La Yerba III) were buried below the floor of a house, flexed, with knees drawn toward the chest and wrapped in twined reed matting, Burial 110 was interred in an unlined grave, beyond the main area of excavated house structures in a "hearth/trash dump" (Quilter 1989:123; Supplemental Figure 1).

Figure 5 compares the isotopic data from these Middle Preceramic coastal villages with other published data for the wider Preceramic period. Burial 110's isotopic values are most similar to those of the somewhat later, inland sites (Figure 1) of La Galgada, $80 \mathrm{~km}$ from the sea at 1,100 $\mathrm{m}$ asl (Washburn et al. 2020), and of Kasapata, far inland at $3,400 \mathrm{~m}$ asl in the Cuzco region (Turner et al. 2018). Her isotopic values, akin to inland terrestrial diets, and the unusual aspects of her burial suggest that Burial 110 was a migrant to the coast. While the mechanisms of trade and exchange by which obsidian lithics arrived on the coast from their highland source at Quispisisa remain unknown, the burial of a highland migrant at Paloma certainly hints at direct access interactions with the highlands at this time.

Even excluding the Burial 110 outlier, the isotopic data also show variations in the marine protein consumed by individuals in these Middle Preceramic villages. Interpreting these variations is complicated by pelagic-benthic coupling in the marine ecosystem along this coast driven by deep upwelling. Pelagic carbon sources typically have significantly lower $\delta^{13} \mathrm{C}$ values than benthic sources (France 1995), so that when pelagicderived materials such as phytoplankton are transported by upwelling to be consumed by benthic primary consumers and thereby transferred to higher trophic levels in the food web, they in turn yield complex isotopic patterns in their own consumers. Filter-feeding bivalves from northern Chile, for instance, have carbon isotope values that are on average $4.2 \%$ lower than those of grazing gastropods collected from the same location, while their nitrogen isotope values are broadly similar (Docmac et al. 2017). This is consistent with those bivalves consuming pelagic-derived phytoplankton, whereas the gastropods consume benthic macroalgae. Benthivorous fish from these locations have carbon isotope values showing diets dominated by pelagic-derived material (and nitrogen isotope values reflective of their higher trophic level than the primary consumers). So, although the isotopic data show differences between, on the one hand, the individuals from La Yerba III and two of the Palomans (Burial 39, PAL06, and Burial 212, PAL21, both adult females) and, on the other hand, the rest of the individuals from Paloma and Chilca I (Figure 5), which may suggest that the former consumed less marine protein than the latter, these data might also reflect a relatively greater consumption of pelagic or pelagic-consuming marine resources. Indeed, 
this interpretation is suggested by the significant proportion of mollusk remains at La Yerba III that are bivalves $(35 \%$ by MNI and $42 \%$ by weight), in particular Mesodesma surf clams; whereas Mesodesma is apparently absent in Paloma's Layer 400 and then only gradually becomes more common in overlying Layers 300 and 200 (Reitz 2003:71).

Figure 5 also shows comparative isotopic data from Morro I (King et al. 2018). Of 18 individuals analyzed, 5 yielded sufficient collagen for reliable isotopic values to be determined. Compared to those of their Middle Preceramic contemporaries at Paloma, Chilca I, and La Yerba III, the isotopic values of four Morro I individuals (T4, T6, T10a, and T12) show higher carbon but generally lower nitrogen isotopic values (Figure 5). This suggests that they consumed greater proportions of marine resources from lower trophic levels, such as shellfish rather than fish, and benthic gastropods rather than pelagic bivalves. The fifth individual (T23C13), meanwhile, likely dates up to two millennia later (Supplemental Table 5) and has isotopic values broadly comparable to those of the Peruvian villages, hinting at greater proportions of marine foods from higher trophic levels over time on the north coast of Chile.

These comparisons seem to be reflected in the wider archaeological record. Even though the archaeological assemblages of Paloma (Benfer 2008; Reitz 2003) and La Yerba III (BeresfordJones et al. 2018) contain a broader range of fish, mollusk, and crustaceans compared with, for instance, Caleta Vitor on the north coast of Chile, the latter becomes more diverse over time (Santoro et al. 2017). Meanwhile, sophisticated fishing technologies are evident at Paloma and La Yerba III in the form of gorges, cactus spine fishhooks, fragments of possible bottle gourd floats for beach seine nets, copious forms of plant fiber cordage, lines, knotted net fragments, and net-making needles (Beresford-Jones et al. 2018). By contrast, in the earlier Chinchorro burials at Morro I contemporaneous with the Middle Preceramic Peruvian villages, there are no nets and limited fishing paraphernalia, which mostly comprise looped fiber bags similar to the "chinguillos" bags used today for collecting mollusks.
The osteological data presented here, meanwhile, show that males and females from Paloma were, on average, taller than those from Morro 1 (Table 2; Supplemental Figure 2). As discussed, relatively poor health among the Chinchorro has been attributed to early sedentism enabled by rich marine productivity on the north coast of Chile, rather than by plant or animal domestication: an hypothesis that would also account for the lack of change in stature after agriculture was adopted (Arriaza and Standen 2008; Supplemental Table 6; Supplemental Figure 2). Palomans, however, seem to have paid little health penalty for their settled lifestyles, as reflected in taller mean stature and lower indicators of nonspecific "stress" compared with their agricultural successors on the central Peruvian coast right through to AD 1000 (Pechenkina et al. 2007). This suggests that sedentism per se does not account for the differences in stature between Paloma and Morro 1, but rather that these variations may be explained by different patterns of marine resource exploitation, reflected in their isotopic and archaeological records and, indeed, analyses of skeletal biomechanics.

Osteological data in many parts of the world confirm other diverse lines of evidence that hunter-gatherers are generally more highly mobile than agriculturalists (Mummert et al. 2011). Yet femoral cross-sectional geometry data from Morro 1 suggest that these individuals were no more habitually mobile than their agricultural successors in the Azapa Valley in northern Chile (Pomeroy 2012; Supplemental Text 1; Supplemental Table 6; Supplemental Figure 2), as reflected also in ${ }^{87} \mathrm{Sr} /{ }^{86} \mathrm{Sr}$ ratios comparable with marine mammals (Standen et al. 2017). Crosssectional geometry of the femur in both males and females at Paloma suggests greater habitual mobility than their counterparts at Morro I.

Previously, longue durée ENSO conditions (Carré et al. 2014) underpinning environmental abundance and seasonal predictability have been proposed as enabling Middle Preceramic (fisher) hunter-gatherers to reduce their mobility and settle at locations where different habitats conjoined, such as those of Paloma, Chilca I, and La Yerba III (Beresford-Jones et al. 2015). The archaeological records of these first permanent villages include resources gathered from those 
habitats according to rounds of logistical mobility (sensu Binford 1980): ephemeral lomas fog oases, in-shore marine pelagic and benthic habitats (including estuarine, sandy beach and rocky headland); and riverine oases (Beresford-Jones et al. 2015; Engel 1988; Weir and Derring 1986). For instance, $85 \%$ of guanaco bones recorded at $\mathrm{La}$ Yerba III are of meatier hind leg parts, suggesting that they were butchered at distant kill sites for transport and consumption in the village. Before riverine oases were altered entirely by agriculture, guanaco likely migrated between winter lomas and summer Andean footslopes, thereby shaping rounds of hunter transhumance (Custred 1979). Such patterns of seasonal logistical mobility are reflected in Palomans' osteological data.

While all people along this Pacific littoral relied on marine resources during the Middle Preceramic, they exploited the sea in different ways. Whereas the inhabitants of the first Peruvian villages employed diverse technologies to harvest a broad range of marine and terrestrial resources in seasonal rounds of logistical mobility, those on the north coast of Chile at this time consumed a more limited range of marine resources, which constituted an even more significant protein component of their diet and were gathered according to less mobile lifestyles.

Finally, even though comparative isotopic data for the long Preceramic are still limited, that data seem to reflect general trends resonant with the wider archaeological record, including changes in the mix between marine and terrestrial resources, different kinds of marine resources, or both (Figure 5). Isotopic data from five individuals from Huaca Prieta's Middle Preceramic Phase 3 (6538-5308 cal BP) and eight from its Late Preceramic Phase 4 (5308-4107 cal BP) in Chicama (DeSantis et al. 2017), alongside eight individuals from the Late Preceramic (4950-3650 cal BP) site of Bandurria, Norte Chico (Coutts et al. 2011), all show lower $\delta^{13} \mathrm{C}$ and $\delta^{15} \mathrm{~N}$ values than those of Paloma, La Yerba III, Chilca I, and Morro I's older contexts, suggesting that they consumed lower proportions of marine protein, or greater proportions of pelagic or pelagic-consuming marine resources. These changes in the direct signatures of diet likely reflect not only the increasing significance of cultivated food crops into the
Late Preceramic (Dillehay 2017; Pearsall 2008) but also the increasing sophistication of fishing technologies. Larger seine nets made from cultivated cotton, for instance, enabled the harvest of much larger quantities of schooling fish such as anchovy (Beresford-Jones et al. 2018; Bird et al. 1985:225; Moseley 1975), significantly altering the benthic/pelagic balance of marine resources consumed. By the end of this chronological sequence a few individuals from Huaca Prieta's Phase 4 have isotopic values that almost converge with those of individuals with terrestrial diets from the Late Preceramic site of La Galgada, $80 \mathrm{~km}$ inland. Aside from individual tooth samples from Paredones in unspecified chronostratigraphic contexts (Figure 5; DeSantis et al. 2017; Tung et al. 2020), and pace the suggestions of Haas and colleagues (2013) and others, there is little evidence in any of these isotopic data for significant maize consumption at these time depths, either on the coast or in the highlands (cf. Washburn et al. 2020).

\section{Conclusions}

Isotopic and osteological data presented here from the earliest sedentary villages along the Pacific coast of South America at Paloma, Chilca I, La Yerba III, and Morro I contribute to a gradually emerging picture of changing diet and lifestyle toward the end of the Middle Preceramic around $6000 \mathrm{cal} \mathrm{BP}$. Aridity in this area has preserved a remarkable archaeological record, but quantifying the relative significance of varying ancient diet remains will inevitably be compromised by differential taphonomy, sampling, and analyses. Isotopic data from bone collagen and dentine, by contrast, yield direct evidence of ancient diet - but only reflecting generalized consumption over many years and dominated by protein components, so that all these data are best interpreted through synthesis.

The data presented corroborate the longstanding connection between marine productivity and sedentism along this coast. $\delta^{13} \mathrm{C}$ and $\delta^{15} \mathrm{~N}$ isotopic values affirm the generalized primacy of marine dietary protein sources in the diets of the inhabitants of these villages, despite considerable archaeological evidence for hunted and gathered terrestrial foods and incipient 
agriculture. Yet, since the $\delta^{13} \mathrm{C}$ and $\delta^{15} \mathrm{~N}$ values of collagen reflect mostly and entirely, respectively, the protein component of diet, isotopic data in isolation inadequately reflect low-protein dietary components, not least plants, whose significance is evidenced directly in coprolites and also in copious midden remains. Moreover, human nutrition requires the high nitrogen levels of protein-rich foods to be diluted by the consumption of either carbohydrates or fats (Speth and Spielmann 1983). Midden remains at Paloma and La Yerba III suggest that this requirement was satisfied by fat in hunted marine mammals and by plant foods in the form of gathered tubers and rhizomes and, increasingly, cultivated plants including high-protein beans.

Although this marine isotopic signature is consistent with the sedentism manifest in the permanent architecture, structured burials, and incipient plant cultivation at these early villages, more subtle implications for mobility may also be discerned. A young woman interred in unusual circumstances at Paloma had apparently come from the Andean hinterlands, hinting that these coastal villages obtained highland resources by direct interaction; for instance, the obsidian procured from Quispisisa, which was $300 \mathrm{~km}$ away. Palomans have more marked osteological indicators of habitual mobility than those buried at Morro I and those differences are higher among males, reflecting the rounds of logistical mobility followed by some members of society that are evident in their wider archaeological records. By locating themselves at the confluence of habitats, the inhabitants of these early villages were able to broaden their use of resources and increase their residential settlement. Yet they paid little substantial health penalty for their settled lifestyles, as reflected by their taller mean stature and lower rates of nonspecific "stress" indicators compared with those of their agricultural successors, even more than five millennia later. Contrasting isotopic and osteological patterns in their contemporaries on the north coast of Chile seem to reflect exploitation of a narrower range of marine resources, using different plant fiber fishing technologies and entailing less habitual mobility, in turn resulting in shorter stature and poorer health.
These data contribute to an emerging picture for how increasingly permanent settlement, population density, and social complexity on the Pacific coast of South America laid the foundations for the emergence of Late Preceramic civilization in the wider Andean region. That evidence, now including isotopic data over the longue durée of the Preceramic, suggests that whereas marine protein was always important to coastal diets, through time it was consumed in lower proportions, or included greater proportions of pelagic as opposed to benthic marine resources, each change consistent, respectively, with the increasing cultivation of food crops and of cotton for fishing nets that is manifest in the wider archaeological record of the Late Preceramic.

Acknowledgments. We wish to thank three anonymous reviewers of this article; Catherine Kneale and James Rolfe (University of Cambridge) for their help with mass spectrometry; Vivien Standen, Marietta Ortega, Héctor González, Bernardo Arriaza, and Susanna Monsalve (Museo Arqueológico San Miguel de Azapa, Departamento de Antropología, Universidad de Tarapacá, Chile) and Professor Alex Robling (Indiana University School of Medicine) for their help with osteological sampling and analyses; and the Ministerio de Cultural del Perú (ex-Instituto Nacional de Cultura) for granting permission for fieldwork and the analysis of samples. The work of David G. Beresford-Jones was supported by the Leverhulme Trust (grant number RPG-117) and the late Don Alberto Benavides de la Quintana (grant number RG69428). The work of Emma Lightfoot was supported by the TwoRains project, which was funded by the European Research Council (grant agreement number 648609).

Data Availability Statement. Materials from Paloma and Chilca I are curated at the Museo Nacional de Antropología, Biodiversidad, Agricultura y Alimentación (ex-Centro de Investigaciones de Zonas Áridas), Universidad Nacional Agraria La Molina, Lima, Peru; materials from La Yerba III are curated at the Museo Regional de Ica, Ica, Peru, and from Morro 1 at the Museo Arqueológico San Miguel de Azapa, Departamento de Antropología, Universidad de Tarapacá, Chile. Raw data underlying this article are available at the University of Cambridge's Apollo Repository at https://doi.org/10.17863/CAM.63764.

Supplemental Material. For supplemental material accompanying this article, visit https://doi.org/10.1017/laq.2021.24.

Supplemental Text 1. Methods and Materials.

Supplemental Table 1. New Radiocarbon Dates for Paloma.

Supplemental Table 2. Paloma Radiocarbon Dates Modeled as Phases in Sequence.

Supplemental Table 3. Paloma, Chilca I, La Yerba III, 
and Morro I Radiocarbon Dates Modeled as a Single Phase.

Supplemental Table 4. Breakdown of the Osteological Sample.

Supplemental Table 5. Chronology of Morro I Burials.

Supplemental Table 6. Comparison of Mean Estimated Adult Statures and Indicators of Habitual Mobility for Morro 1 Hunter-Gatherers and Azapa Valley Agriculturalists.

Supplemental Figure 1. Burials at La Yerba III and Paloma.

Supplemental Figure 2. Box-and-whisker plots of (A) stature and (B) femoral midshaft $I_{\max } / I_{\min }$ ratios across different levels at Paloma and at Morro 1; and (C) stature and (D) femoral midshaft $I_{\max } / I_{\min }$ ratios for Morro 1 hunter-gatherers and Azapa Valley agriculturalists.

\section{Note}

1. The "Middle Preceramic" (Quilter 1991) is also known as the "Middle Archaic" in Peru. The approximately coincident period in Chile is referred to as the "Late Archaic" (7500-4000 cal BP; Ugalde et al. 2021). Here we subsume these all under the "Middle Preceramic" to highlight the broad comparability in human ecology and aspects of material culture along the Pacific littoral between $30^{\circ} \mathrm{S}$ in Chile and $5^{\circ} \mathrm{S}$ in Peru before around $5000 \mathrm{cal} \mathrm{BP}$.

\section{References Cited}

Ambrose, Stanley H., and Lynette Norr

1993 Isotopic Composition of Dietary Protein and Energy versus Bone Collagen and Apatite: Purified Diet Growth Experiments. In Prehistoric Human Bone: Archaeology at the Molecular Level, edited by Joseph Lambert and Grisela Grupe, pp. 1-37. Springer-Verlag, New York.

Arriaza, Bernardo T., and Vivien G. Standen

2006 Skeletal Robusticity and Economies of the Ancient Arican Populations in Northern Chile [abstract]. American Journal of Physical Anthropology 129(S42):58.

Arriaza, Bernardo T., and Vivien G. Standen

2008 Bioarqueología: Historia biocultural de los antiguos pobladores del extremo norte de Chile. Editorial Universitaria, Santiago, Chile.

Bearez, Phillipe, Felipe Fuentes-Mucherl, Sandra Rebolledo, Diego Salazar, and Laura Olguin

2016 Billfish Foraging along the Northern Coast of Chile during the Middle Holocene (7400-5900 cal BP). Journal of Anthropological Archaeology 46:185-195.

Benfer, Robert A.

1984 The Challenges and Rewards of Sedentism: The Preceramic Village of Paloma, Peru. In Paleopathology at the Origins of Agriculture, edited by Mark N. Cohen and George J. Armelagos, pp. 531-558. Academic Press, Orlando, Florida.

2008 Early Villages. In Encyclopedia of Archaeology, Vol. 1, edited by Deborah M. Pearsall, pp. 368-380. Academic Press, New York.

Beresford-Jones, David G., Alexander G. Pullen, George Chauca, Lauren Cadwallader, Maria García, Isabel Salvatierra, Oliver Q. Whaley, Victor Vásquez, Susana Arce, Kevin Lane, and Charles French

2018 Refining the Maritime Foundations of Andean Civilization: How Plant Fiber Technology Drove Social
Complexity during the Preceramic Period. Journal of Archaeological Method and Theory 25:393-425.

Beresford-Jones, David G., Alexander G. Pullen, Oliver Q. Whaley, Justin Moat, George Chauca, Lauren Cadwallader, Susana Arce, Alfonso Orellana, Carmela Alarcón, Manuel Gorriti, Patricia Maita, Fraser Sturt, Agathe Dupeyron, Oliver Huaman, Kevin Lane, and Charles French.

2015 Re-evaluating the Resource Potential of Lomas Fog Oasis Environments for Preceramic Hunter-Gatherers under Past ENSO Modes on the South Coast of Peru. Quaternary Science Reviews 129:196-215.

Binford, Lewis R.

1980 "Willow Smoke and Dogs Tails": Hunter-Gatherer Settlement Systems and Archaeological Site Formation. American Antiquity 45:4-20.

Bird, Junius B., John Hyslop, and Milica D. Skinner

1985 The Preceramic Excavations at the Huaca Prieta Chicama Valley, Peru. Anthropological Papers Vol. 62, Pt. 1. American Museum of Natural History, New York. Bocherens, Hervé, and Dorothée Drucker

2003 Trophic Level Isotopic Enrichment of Carbon and Nitrogen in Bone Collagen: Case Studies from Recent and Ancient Terrestrial Ecosystems. International Journal of Osteoarchaeology 13:46-53.

Bogin, Barry, and R. Keep

1999 Eight Thousand Years of Economic and Political History in Latin America Revealed by Anthropometry. Annals of Human Biology 26:333-351.

Bonavia, Duccio, Víctor F. Vásquez, Teresa Rosales Tham, Tom D. Dillehay, Patricia J. Netherly, and Kristin Benson

2017 Plant Remains. In Where the Land Meets the Sea: Fourteen Millennia of Human History at Huaca Prieta, Peru. edited by Tom D. Dillehay, pp. 367-433. University of Texas Press, Austin.

Bronk Ramsey, Christopher

2009 Bayesian Analysis of Radiocarbon Dates. Radiocarbon 51:337-360.

Cadwallader, Lauren, David G. Beresford-Jones, Oliver Q. Whaley, and Tamsin C. O'Connell

2012 The Signs of Maize? A Reconsideration of What $\delta^{13} \mathrm{C}$ Values Say about Palaeodiet in the Andean Region. Human Ecology 40:487-509.

Carré, Matthieu, Julian P. Sachs, Sara Purca, Andrew J. Schauer, Pascale Braconnot, Rommel A. Falcon, Michèle Julien, and Danièle Lavallée

2014 Holocene History of ENSO Variance and Asymmetry in the Eastern Tropical Pacific. Science 345:1045-1048.

Chauca, George, Michael Glascock, Jorge Rodríguez, Susana Arce S., and David G. Beresford-Jones

2019 El vidrio volcánico del litoral de Ica durante el Precerámico Medio (8000-5000 AP). In Actas del V Congreso Nacional de Arqueología, Vol. I, pp. 177-185. Ministerio de Cultura, Lima.

Cohen, Mark N., and George J. Armelagos (editors)

1984 Paleopathology at the Origins of Agriculture. Academic Press, London.

Coutts, Karen H., Alejando Chu, and John Krigbaum

2011 Paleodiet in LatePreceramic Peru: Preliminary Isotopic Data from Bandurria. Journal of Island and Coastal Archaeology 6:196-210.

Custred, Glynn

1979 Hunting Technologies in Andean Culture. Journal de la Société des Américanistes 66:7-19. 
DeSantis, Larisa R. G., Tom D. Dillehay, Steven L. Goodbred Jr., and Robert S. Feranec

2017 Appendix 6: Dietary Ecology, Stable Isotope, and Dental Microwear Texture Analysis. In Where the Land Meets the Sea: Fourteen Millennia of Human History at Huaca Prieta, Peru, edited by Tom D. Dillehay, pp. 665-673. University of Texas Press, Austin.

Dillehay, Tom D. (editor)

2017 Where the Land Meets the Sea: Fourteen Millennia of Human History at Huaca Prieta, Peru. University of Texas Press, Austin.

Docmac, Felipe, Miguel Araya, Ivan A. Hinojosa, Cristina Dorador, and Chris Harrod

2017 Habitat Coupling Writ Large: Pelagic-Derived Materials Fuel Benthivorous Macroalgal Reef Fishes in an Upwelling Zone. Ecology 98:2267-2272.

Engel, Frédéric A.

1980 Prehistoric Andean Ecology: Man, Settlement and Environment in the Andes, Vol. 1: Paloma Village 613. Humanities Press, New York.

1988 Ecologia prehistorica andina: Chilca I. Implementos de hueso. CIZA, La Univerisdad Nacional Agraria del Perú, Lima.

1991 Un desierto en tiempos prehispanicos. La UniverisFAO dad Nacional Agraria del Perú, Lima.

2014. Fish, Crustaceans, Molluscs, etc.: Capture Production by Principal Species in 2012 FAO Fisheries Statistics. Electronic document, ftp://ftp.fao.org/FI/STAT/ summary/a1e.pdf, accessed October 12, 2014.

France, Robert

1995 Carbon-13 Enrichment in Benthic Compared to Planktonic Algae: Foodweb Implications. Marine Ecology Progress Series 124:307-312.

Gage, John P., Martin J. O. Francis, and James T. Triffitt 1989 Collagen and Dental Matrices. Wright, London.

Gorbahn, Hermann

2020 Pernil Alto: An Agricultural Village of the Middle Archaic Period in Southern Peru. Forschungen zur Archäologie Außereuropäischer Kulturen Band 17. Harrassowitz, Wiesbaden, Germany.

Grobman Alexander, Duccio Bonavia, Tom D. Dillehay, Dolores R. Piperno, José Iriarte, and Irene Holst

2012 Preceramic Maize from Paredones and Huaca Prieta, Peru. PNAS 109:1755-1759.

Haas, Jonathan, Winifred Creamer, Luis Huamán Mesía, David Goldstein, Karl Reinhard, and Cindy Vergel Rodríguez

2013 Evidence for Maize (Zea mays) in the Late Archaic (3000-1800 BC) in the Norte Chico Region of Peru. PNAS 110:4945-4949.

Hedges, Robert E. M.

2003 On Bone Collagen-Apatite-Carbonate Isotopic Relationships. International Journal of Osteoarchaeology 13:66-79.

Hedges, Robert E. M., John G. Clement, David L. Thomas, and Tamsin C. O'Connell

2007 Collagen Turnover in the Adult Femoral Mid-Shaft: Modeled from Anthropogenic Radiocarbon Tracer Measurements. American Journal of Physical Anthropology 133:808-816.

Hogg, Alan G., Quan Hua, Paul G. Blackwell, Mu Niu, Caitlin E. Buck, Thomas P. Guilderson, Timothy J. Heaton, Jonathan G. Palmer, Paula J. Reimer, Ron W. Reimer, Christian S. M. Turney, and Susan R. H. Zimmerman

2013 SHCal13 Southern Hemisphere Calibration, 0 50,000 Years cal BP. Radiocarbon 55:1889-1903.
Kaplan, Lawrence, and Thomas F. Lynch

1999 Phaseolus (Fabaceae) in Archaeology: AMS Radiocarbon Dates and their Significance for Pre-Columbian Agriculture. Economic Botany 53:261-272.

King, Charlotte L., Andrew R. Millard, Darren R. Gröcke, Vivien G. Standen, Bernardo T. Arriaza, and Siân E. Halcrow

2018 Marine Resource Reliance in the Human Populations of the Atacama Desert, Northern Chile-A View from Prehistory. Quaternary Science Reviews 182:163-174.

Larsen, Clark S.

2006 The Agricultural Revolution as Environmental Catastrophe: Implications for Health and Lifestyle in the Holocene. Quaternary International 150:12-20.

Lee-Thorp, Julia A.

2008 On Isotopes and Old Bones. Archaeometry 50:925950.

Mercader, Julio, Mariam Bundala, Matthew J. Collins, Les Copeland, Alison Crowther, Amanda Henry, Makarius Itambu, Steve Larter, Laura Longo, Robert Patalano, Ramaswami Sammynaiken, Robert Tyler, and Hermine Xhauflair

2018 Exaggerated Expectations in Ancient Starch Research and the Need for Best Practices and Authenticity Criteria. Facets 3:777-797.

Moseley, Michael E.

1975 The Maritime Foundations of Andean Civilization. Cummings Publishing, Menlo Park, California.

Mummert, Amanda, Emily Esche, Joshua Robinson, and George J. Armelagos

2011 Stature and Robusticity during the Agricultural Transition: Evidence from the Bioarchaeological Record. Economics and Human Biology 9:284-301.

O'Connell, Tamsin C., Catherine J. Kneale, Natasha Tasevska, and Gunter G. C. Kuhnle

2012 The Diet-Body Offset in Human Nitrogen Isotopic Values: A Controlled Dietary Study. American Journal of Physical Anthropology 149:426-434.

O'Leary, Marion $\mathrm{H}$.

1988 Carbon Isotopes in Photosynthesis. BioScience 38:328-336.

Pearsall, Deborah

2008. Plant Domestication and the Shift to Agriculture in the Andes. In Handbook of South American Archaeology, edited by Helaine Silverman and William H. Isbell, pp. 105-120. Springer-Verlag, New York.

Pechenkina, Ekaterina A., Joseph A. Vradenburg, Robert A. Benfer, and Julie F. Farnum

2007 Skeletal Biology of the Central Peruvian Coast: Consequences of Changing Population Density and Progressive Dependence on Maize Agriculture. In Ancient Health: Skeletal Indicators of Agricultural and Economic Intensification, edited by Mark Nathan Cohen and Gillian M. M. Crane-Kramer, pp. 92-112. University Press of Florida, Gainesville.

Pomeroy, Emma

2012 The Bioarchaeology of Adaptation to Andean Environments: A Combined Osteometric and Anthropometric Approach. PhD dissertation, Division of Biological Anthropology, University of Cambridge, Cambridge.

Pomeroy, Emma, and Jay T. Stock

2012 Estimation of Stature and Body Mass from the Skeleton among Coastal and Mid-Altitude Andean Populations. American Journal of Physical Anthropology 147:264-279. 
Prieto, Gabriel, and Daniel H. Sandweiss (editors) 2020 Maritime Communities of the Ancient Andes. University Press of Florida, Gainesville.

Privat, Karen L., Tamsin C. O'Connell, and Michael P. Richards

2002 Stable Isotope Analysis of Human and Faunal Remains from the Anglo-Saxon Cemetery at Berinsfield, Oxfordshire: Dietary and Social Implications. Journal of Archaeological Science 29:779-790.

Quilter, Jeffrey

1989 Life and Death at Paloma: Society and Mortuary Practices in a Preceramic Peruvian Village. University of Iowa Press, Iowa City.

1991 Late Preceramic Peru. Journal of World Prehistory 5:387-438.

Reinhard, Karl J., Sara LeRoy-Toren, and Bernardo T. Arriaza

2011 Where Have All the Plant Foods Gone? The Search for Refined Dietary Reconstruction from Chinchorro Mummies. Yearbook of Mummy Studies 1:139-151.

Reitz, Elizabeth J.

2003 Resource Use through Time at Paloma Peru. Bulletin of the Florida Museum of Natural History 44:65-80.

Ruff, Christopher B.

2008 Biomechanical Analyses of Archaeological Human Skeletons. In Biological Anthropology of the Human Skeleton, 2nd ed., edited by M. Anne Katzenberg and Shelley R. Saunders, pp. 183-206. Wiley-Liss, Hoboken, New Jersey.

Ruff, Cristopher B., Clark Spencer Larsen, and Wilson C. Hayes

1984 Structural Changes in the Femur with the Transition to Agriculture on the Georgia Coast. American Journal of Physical Anthropology 64:125-136.

Salazar, Diego, Camila Arenas, Pedro Andrade, Laura Olguin, Jimena Torres, Carola Flores, Gabriel Vargas, Sandra Rebolledo, Cesar Borie, Consuelo Sandoval, Claudia Silva, Ayelen Delgado, Nicolas Lira, and Camilo Robles

2018 From the Use of Space to Territorialisation during the Early Holocene in Taltal, Coastal Atacama Desert, Chile. Quaternary International 473:225-241.

Sandweiss, Daniel H., Fred T. Andrus, Alice R. Kelley, Krik A. Maasch, Elizaeth J. Reitz, and Paul B. Roscoe

2020. Archaeological Climate Proxies and the Complexities of Reconstructing Holocene El Niño in Coastal Peru. PNAS 117:8271-8279.

Santoro, Calogero M., Eugenia M. Gayo, Chris Carter, Vivien G. Standen, Victoria Castro, Daniela Valenzuela, Ricardo De Pol-Holz, Pablo A. Marquet, and Claudio Latorre

2017 Loco or No Loco? Holocene Climatic Fluctuations, Human Demography, and Community Based Management of Coastal Resources in Northern Chile. Frontiers in Earth Science 5:77.

Speth, John D., and Katherine A. Spielmann

1983 Energy Sources, Protein Metabolism, and HunterGatherer Subsistence Strategies. Journal of Anthropological Archaeology 2:1-31.

Standen, Vivien G.

1997 Temprana Complejidad Funeraria de la Cultura Chinchorro (Norte de Chile). Latin American Antiquity 8:134-156.
2003 Bienes funerarios del cementerio Chinchorro Morro 1: Descripción, análisis e interpretación. Chungara 35:175-207.

Standen, Vivien, C. Santoro, Bernardo T. Arriaza, and Drew Colleman

2017 Hunting, Gathering, Fishing on the Coast of the Atacama Desert: Chinchorro Population Mobility Patterns Inferred from Strontium Isotopes. Geoarchaeology 33:162-176.

Steckel, Richard $\mathrm{H}$.

2009 Heights and Human Welfare: Recent Developments and New Directions. Explorations in Economic History 46:1-23.

Stiner, Mary C.

2001 Thirty Years on the "Broad Spectrum Revolution" and Paleolithic Demography. PNAS 98:6993-6996.

Tanner, James M.

1987 Growth as a Mirror of the Condition of Society: Secular Trends and Class Distinctions. Pediatrics International 29:96-103.

Tieszen, Larry L., and Tim Fagre

1993 Effect of Diet Quality on the Isotopic Composition of Respiratory $\mathrm{CO}_{2}$, Bone Collagen, Bioapatite and Soft Tissues. In Prehistoric Human Bone: Archaeology at the Molecular Level, edited by Joseph B. Lambert and Grisela Grupe, pp. 121-155. Springer-Verlag, Berlin.

Tung, Tiffany A., Tom D. Dillehay, Robert S. Feranec, and Larisa R. G. DeSantis

2020 Early Specialized Maritime and Maize Economies on the North Coast of Peru. PNAS 117:32308-32319.

Turner, Bethany L., Véronique Bélisle, Allison R. Davis, Maeve Skidmore, Sara L. Juengst, Benjamin J. Schaefer, R. Alan Covey, and Brian S. Bauer

2018 Diet and Foodways across Five Millennia in the Cusco Region of Peru. Journal of Archaeological Science 98:137-148.

Ugalde, Paula C., Virginia McRostie, Eugenia M. Gayo, Magdalena Garcia, Claudio Latorre, and Calogero M. Santoro

2021 13,000 Years of Sociocultural Plant Use in the Atacama Desert of Northern Chile. Vegetation History and Archaeobotany 30:213-230. DOI:10.1007/s00334-02000783-1.

Washburn, Eden, Jason Nesbitt, Richard Burger, Elsa Tomasto-Cagigao, Vicky M. Oelze, and Lars FehrenSchmitz

2020 Maize and Dietary Change in Early Peruvian Civilization: Isotopic Evidence from the Late Preceramic Period/Initial Period Site of La Galgada, Peru. Journal of Archaeological Science: Reports 31:102-309.

Weir, Glendon W., and J. Phillip Derring

1986 The Lomas of Paloma: Human-Environment Relations in a Central Peruvian Fog Oasis: Archaeobotany and Palynology. In Andean Archaeology: Papers in Memory of Clifford Evans, edited by Ramiro MatosMendieta, Solveig A. Turpin, and Herbert H. Eling, pp. 18-44. Institute of Archaeology, University of California, Los Angeles.

Submitted January 21, 2020; Revised June 9, 2020; Accepted January 25, 2021 